\title{
DNA Repair Protein Involved in Heart and Blood Development ${ }^{\nabla}$
}

\author{
Yi Wang, Craig C. Shupenko, Luisa F. Melo, and Phyllis R. Strauss* \\ Department of Biology, Northeastern University, Boston, Massachusetts 02115
}

Received 5 July 2006/Returned for modification 21 July 2006/Accepted 25 August 2006

\begin{abstract}
Apurinic/apyrimidinic endonuclease 1, a key enzyme in repairing abasic sites in DNA, is an embryonic lethal in mice. We are examining its role in embryogenesis in zebra fish. Zebra fish contain two genomic copies (zfAPEX1a and zfAPEX1b) with identical coding sequences. zfAPEX1b lacks introns. Recombinant protein (ZAP1) is highly homologous with and has the same enzymatic properties as its human orthologue. ZAP1 is highly expressed throughout development. Embryos microinjected with morpholino oligonucleotide (MO) targeting the translation start site die at approximately the midblastula transition (MBT) without apoptosis. They are rescued with mRNA for human wild-type APEX1 but not for APEX1 encoding endonuclease-defective protein. Rescued embryos develop dysmorphic hearts, pericardial edema, few erythrocytes, small eyes, and abnormal notochords. Although the hearts in rescued embryos form defective loops ranging from no loop to one that is abnormally shaped, cardiac myosin (cmlc2) is present and contraction occurs. Embryos microinjected with MO targeting zfAPEX1a intron-exon junctions also pass the MBT with similar abnormalities. We conclude that AP endonuclease 1 is involved in both repairing DNA and regulating specific early stages of embryonic development.
\end{abstract}

Abasic sites arise in DNA at a significant rate by spontaneous base loss as in depurination, by DNA oxidation (29), or by the action of DNA glycosylases $(9,14,27)$. Estimates of the number of abasic sites generated per mammalian cell run as high as 50,000 to 200,000 per day (37). Unrepaired abasic sites inhibit topoisomerases (53), replication, and transcription (57) and can be mutagenic because of bypass synthesis on nontemplated DNA $(26,49)$. Despite the large number of abasic sites generated per cell per day, the number of resulting mutations is extremely low. The difference reflects the elaborate mechanisms that the cell has devised to repair abasic sites $(14,29)$. One of the key enzymes in abasic site repair is apurinic/apyrimidinic endonuclease (AP endo; also called Apex, HAP, and REF1). The predominant AP endo in mammalian cells, AP endo 1 , is a multifunctional enzyme that hydrolyzes the phosphodiester bond $5^{\prime}$ to an abasic site $(23,30,34,36,41,42,52)$. Cleavage generates a $3^{\prime}$ hydroxyl terminus suitable for extension by a DNA polymerase and a downstream $5^{\prime}$ terminus with a deoxyribose phosphate residue (dRP) that must be removed and replaced so that the two strands can be ligated in order to complete repair.

AP endo 1 is a highly conserved enzyme with similar proteins found at all levels of organismal complexity (38). It accounts for ca. $95 \%$ of all endonuclease activity in the mammalian cell (14). Beyond its 5' AP endonuclease activity, AP endo also exhibits secondary catalytic functions, including $3^{\prime}$ exonuclease, 3' dRPase, 3' phosphodiesterase, and RNase $\mathrm{H}$ activities and the ability to cleave abasic sites in single-stranded DNA $(10,33,38)$. Interestingly, AP endo may have a function as a regulatory protein, since it has been reported to stimulate the binding of certain transcription factors, including c-Jun (40),

* Corresponding author. Mailing address: Northeastern University, Department of Biology, 360 Huntington Ave., Boston, MA 02115. Phone: (617) 373-3492. Fax: (617) 373-2138. E-mail: p.strauss@neu .edu.

${ }^{\nabla}$ Published ahead of print on 11 September 2006.
c-Fos (55), and p53 (22), to their cognate DNA sequences. Furthermore, AP endo participates in the SET complex involved in granzyme A-mediated apoptosis (12). Experiments in mammalian cells have indicated that reduced amounts of functional AP endo result in increased sensitivity to methyl methanesulfonate, $\mathrm{H}_{2} \mathrm{O}_{2}$, menadione, paraquat, and ionizing radiation (7), and reducing AP endo levels in several cell lines by means of RNA interference leads to increased apoptosis $(15,47)$.

The knockout mutation for AP endo in mice is lethal, and no viable null cell line has been created, leaving open the possibility that AP endo is critical for development. In an attempt to find alternative ways to study the role of AP endo in vivo and in situ, we turned to zebra fish (Danio rerio), which provides the appropriate vertebrate system for genetic and protein manipulation. Because the eggs are externally fertilized and transparent through early development, the investigation has easy access to all developmental stages. Zebra fish have a relatively short generation time of 2 to 3 months, they generate large numbers of progeny that develop rapidly, and the genome is currently being sequenced. Furthermore, zebra fish early development is remarkably similar to development in mammals, and specific genes can be knocked down shortly after fertilization with morpholino oligonucleotides (MOs) so that their roles in early development can be examined.

In this report we provide data that show not only that AP endo is required for cell viability but also that when its concentration is altered in the early embryo, specific developmental defects arise.

\section{MATERIALS AND METHODS}

Zebra fish lines. All experiments were carried out with wild-type Tuebingen Long Fin embryos, except those using transgenic cmlc2:GFP fish (4). Breeding and staging of embryos were performed according to standard protocols. For each experiment, a single clutch containing 300 or more embryos was used, with a minimum of 46 embryos per condition. Each experiment was repeated at least three times. Experiments were discarded if $>2 \%$ of controls failed to divide to the two-cell stage in $\mathrm{H}_{2} \mathrm{O}$-injected embryos. 
Production and labeling of EST fragment. A 348-bp DNA probe was prepared from a zebra fish expressed sequence tag (EST) template (GenBank accession no. AI877862; Washington University EST no. fc54d10.y1) that showed homology to the N-terminal domain of human AP endo (amino acid residues 22 to 132). The fragment was amplified from zebra fish genomic DNA via PCR using primers designed from the EST. The PCR protocol began with 3 min at $94^{\circ} \mathrm{C}$, followed by 35 polymerization cycles $\left(94^{\circ} \mathrm{C}\right.$ for $1 \mathrm{~min}, 58^{\circ} \mathrm{C}$ for $2 \mathrm{~min}$, and $72^{\circ} \mathrm{C}$ for $2.5 \mathrm{~min}$ ) using forward primer ZF1 (GGA TCC TGG AGA GGC TGA CAA) and reverse primer ZF2 (GGA TCC GCC ACT CCA CTG TAG CCC). The resulting fragment was ligated into cloning vector pCR2.1-TOPO (Invitrogen/Life Technologies, Carlsbad, CA) according to the manufacturer's protocol for blunt-end ligation and transformed into Escherichia coli DH5 $\alpha$. Plasmid DNA was isolated from ampicillin-resistant cells by using a QIAGEN plasmid MaxiPrep kit (QIAGEN, Inc., Valencia, CA). The insert, which had been sequenced, was excised from the vector by EcoRI digestion and purified by gel separation and extraction using a QIAGEN gel extraction kit and protocol. The purified 348-bp probe was radioactively labeled with $\left[\alpha^{32} \mathrm{P}\right] \mathrm{CTP}$ using the Prime-It II random primer oligonucleotide labeling kit (Stratagene Cloning Systems, La Jolla, CA).

Identification of zebra fish apurinic/apyrimidinic endonuclease 1 gene (zfAPEX1) cDNA. An 8-h-postfertilization (hpf) zebra fish library constructed in a pSPORT vector, obtained from the P. Yelick laboratory (Forsyth Institute, Boston, MA) and transformed into E. coli, was screened with the 348-bp probe by using the colony lift technique on nylon membranes (39). The plates were placed in a $37^{\circ} \mathrm{C}$ incubator for $5 \mathrm{~h}$ to allow colony regrowth in preparation for colony isolation. The colony DNA was fixed to the nylon by baking in a vacuum oven at $80^{\circ} \mathrm{C}$ and $30 \mathrm{lb} / \mathrm{in}^{2}$ for $2 \mathrm{~h}$. After prehybridization with $5 \times \operatorname{SSPE}(0.75 \mathrm{M}$ $\mathrm{NaCl}, 0.05 \mathrm{M} \mathrm{NaH}_{2} \mathrm{PO}_{4}, 5 \mathrm{mM}$ EDTA) and $5 \times$ Denhardt solution (0.1\% Ficoll $400,0.1 \%$ polyvinylpyrrolidone, $0.1 \%$ bovine serum albumin [BSA]) containing $100 \mathrm{mg}$ of sonicated salmon sperm $\mathrm{DNA} / \mathrm{ml}$ and $0.5 \%$ sodium dodecyl sulfate (SDS) at $65^{\circ} \mathrm{C}$ for $1.5 \mathrm{~h}$, the membranes were allowed to hybridize with $50 \mathrm{ng}$ of labeled probe for $16 \mathrm{~h}$ at $65^{\circ} \mathrm{C}$. After hybridization was complete, the membranes were washed twice for $5 \mathrm{~min}$ at room temperature in $2 \times$ SSC $(1 \times$ SSC is $0.15 \mathrm{M}$ $\mathrm{NaCl}$ plus $0.015 \mathrm{M}$ sodium citrate) $-0.1 \%$ SDS, once for $15 \mathrm{~min}$ at $65^{\circ} \mathrm{C}$ in $0.2 \times$ SSC $-0.1 \%$ SDS, and once in $0.2 \times$ SSC $-0.1 \%$ SDS at $65^{\circ} \mathrm{C}$ for $45 \mathrm{~min}$. The presence of colonies containing plasmid positive for the probe was determined by PhosphorImager analysis. Positive colonies were subcloned until uniform hybridization was obtained. Isolates were then grown in bulk culture for Maxi-Prep isolation of plasmid DNA by using a QIAGEN Maxi-Prep kit. DNA from each clone was subjected to restriction endonuclease analysis, and inserts that exhibited patterns consistent with that of a full-length APEX1 clone were sequenced (Harvard Medical School Bio-Polymer Facility, Boston, MA).

RNA preparation, reverse transcription-PCR (RT-PCR), $5^{\prime}$ and $3^{\prime}$-RACE, and molecular cloning. Total RNA was isolated by using the TRIzol reagent (Invitrogen, Carlsbad, CA), according to the manufacturer's instructions. An antisense oligodeoxynucleotide primer for $5^{\prime}$-RACE $\left(5^{\prime}\right.$ rapid amplification of cDNA ends; 5'-CGG TAG TCA AGC CGC ACA AAC CAC GAC TGG C-3') and a sense oligodeoxynucleotide primer for $3^{\prime}$-RACE (5'-TAT GGC ATT GGT AAA CCA CGA CTG GC-3') were constructed. First-strand cDNA synthesis and subsequent amplification of the $5^{\prime}$ and $3^{\prime}$ cDNA ends were performed according to the instruction manual of the SMART RACE cDNA amplification kit (Clontech BD Biosciences, Palo Alto, CA). 5'-RACE and 3'-RACE used the following PCR conditions. After an initial denaturation of 1 cycle at $94^{\circ} \mathrm{C}$ for 2 min, the mixture was amplified for 20 cycles of $94^{\circ} \mathrm{C}$ for $45 \mathrm{~s}, 68^{\circ} \mathrm{C}$ for $45 \mathrm{~s}$, and $72^{\circ} \mathrm{C}$ for $3 \mathrm{~min}$. All of the RACE-derived PCR products were subcloned into the pCR-XL-TOPO vector (Invitrogen) according to the manufacturer's instructions and sequenced (Tufts University Core Research Facility, Boston, MA).

Genomic PCR. Genomic DNA was isolated from whole adult zebra fish according to previously published protocols (51). Genomic PCR was performed by using Elongase enzyme mix (Invitrogen). PCR mixtures contained $5 \mathrm{U}$ of $\mathrm{Taq}$ DNA polymerase, deoxynucleotide mix $(0.2 \mathrm{mM}$ each $), 1 \times$ PCR buffer $[60 \mathrm{mM}$ Tris-SO $\mathrm{SO}_{4}$ (pH 9.1), $18 \mathrm{mM}\left(\mathrm{NH}_{4}\right)_{2} \mathrm{SO}_{4}, 15 \mathrm{mM} \mathrm{MgSO}_{4}$ ], forward primer 5'-CTT ATA TTT CGG TCA GGC-3' $(0.2 \mu \mathrm{M})$, reverse primer $5^{\prime}$-CCA CCA TGA TCC CCT T-3' $(0.2 \mu \mathrm{M})$, and $300 \mathrm{ng}$ of template (genomic DNA). Preamplification denaturation $\left(68^{\circ} \mathrm{C}\right.$ for $\left.30 \mathrm{~s}\right)$ was performed once, followed by 35 cycles of denaturation $\left(30 \mathrm{~s}\right.$ at $\left.95^{\circ} \mathrm{C}\right)$, annealing $\left(30 \mathrm{~s}\right.$ at $\left.55^{\circ} \mathrm{C}\right)$, and elongation $(5 \mathrm{~min}$ at $\left.68^{\circ} \mathrm{C}\right)$.

Southern blot analysis. Genomic DNA $(40 \mu \mathrm{g})$ was subjected to digestion with NdeI, EcoRV/NdeI, or HindIII/NdeI for $18 \mathrm{~h}$ (New England Biolabs, Beverly, $\mathrm{MA}$ ). Electrophoresis was performed in $1 \times \mathrm{TAE}$ at a continuous voltage of 25 $\mathrm{V}$ for $24 \mathrm{~h}$. DNA was transferred overnight to a charged nylon membrane (Schleicher \& Schuell, Dassel, Germany) via osmotic transfer with denaturing alkaline transfer buffer $(0.4 \mathrm{~N} \mathrm{NaOH}, 1 \mathrm{M} \mathrm{NaCl})$. After transfer, the membrane was fixed in neutralization buffer $(0.5 \mathrm{M}$ Tris- $\mathrm{Cl}[\mathrm{pH} 7.2], 1 \mathrm{M} \mathrm{NaCl})$ for $15 \mathrm{~min}$ and then prehybridized at $60^{\circ} \mathrm{C}$ for $1 \mathrm{~h}$. Radiolabeled zebra fish cDNA encoding region sequences were prepared by random priming of zfAPEX1 cDNA using the Prime-It II kit (Stratagene Cloning Systems). After prehybridization, the prepared membrane was hybridized in a Seal-a-Meal bag with $25 \mathrm{ng}$ of labeled probe in hybridization solution and hybridized for $2 \mathrm{~h}$ at $60^{\circ} \mathrm{C}$ (ExpressHyb hybridization solution; BD, Palo Alto, CA), followed by washings as described by the manufacturer. Distribution of annealed radiolabeled probe was determined by PhosphorImager analysis.

Northern blot analysis. Total RNA was isolated from adult fish by using TRIzol reagent (Invitrogen) as outlined by the manufacturer. Gel electrophoresis and blotting onto nylon membrane (NYTRAN Superchange; Schleicher \& Schuell, Dassel, Germany) were performed as described by the manufacturer. The radiolabeled zebra fish cDNA encoding region (see Fig. 2C) or $\sim 297$ bp in the $3^{\prime}$-untranslated region (3'UTR) of the long copy (see Fig. 2C) was prepared by random priming of zfAPEX1 cDNA using the Stratagene Primer-It II kit. Each lane contained $20 \mu \mathrm{g}$ of total RNA. The distribution of radiolabeled probe was determined by PhosphorImager analysis.

Whole-mount in situ hybridization. A plasmid containing zfAPEX1 full-length cDNA was linearized with XhoI restriction endonuclease and transcribed with SP6 RNA polymerase in the presence of digoxigenin-labeled nucleotides (Roche Applied Science, Indianapolis, IN). Whole-mount in situ hybridization was performed according to the standard protocol. Specimens were then examined by light microscopy.

Enzyme expression and purification. The zfAPEX1 encoding region was amplified by PCR from full-length zfAPEX1 cDNA by using the following primers: $5^{\prime}$-ATG CCC AAA AGA GCC AAG AAG-3' and 5'-CTA CAC TGC CAA AAA CAA GGT-3'. The resulting PCR product was ligated into pTricHis2TOPO vector (Invitrogen). The purification protocol was the same as the one used to isolate recombinant human AP endonuclease 1 (HAP1) in this laboratory (41). The insert was sequenced and shown to contain a stop codon inserted in the $3^{\prime}$ terminus of the encoding region. Zebra fish apurinic/apyrimidinic endonuclease 1 protein (ZAP1) was expressed in E. coli strain Top 10 (Invitrogen). After induction with IPTG (isopropyl- $\beta$-D-thiogalactopyranoside) for $2 \mathrm{~h}$, cells from a 2-liter culture were lysed in buffer A (50 mM Tris- $\mathrm{HCl}[\mathrm{pH}$ 7.5], $1 \mathrm{mM}$ EDTA) containing $500 \mathrm{mM} \mathrm{NaCl}, 0.5 \mathrm{mM}$ phenylmethylsulfonyl fluoride, $1.0 \mu \mathrm{g}$ of pepstatin $/ \mathrm{ml}$, and $1 \mathrm{mM}$ dithiothreitol by means of sonic disruption. After the removal of cell debris by centrifugation at $27,000 \times g$ for 15 $\mathrm{min}$, the supernatant fraction was adjusted to $100 \mathrm{mM} \mathrm{NaCl}$ by addition of buffer A containing protease inhibitors and dithiothreitol. This mixture was passed over a Q-Sepharose column (100-ml bed volume) connected in series to an S-Sepharose column of the same size. After a wash with buffer A containing $100 \mathrm{mM}$ $\mathrm{NaCl}$, the S-Sepharose column was developed with increasing concentrations of $\mathrm{NaCl}$ up to $1 \mathrm{M}$. ZAP1, eluting under high-salt conditions $(>500 \mathrm{mM} \mathrm{NaCl})$, was further purified by chromatography over a Mono $\mathrm{S}$ column by fast-performance liquid chromatography (Pharmacia Biotech, Inc.). The purified enzyme eluted from the Mono S column at approximately $450 \mathrm{mM} \mathrm{NaCl}$. N-terminal analysis confirmed that the isolated protein conformed to the predicted sequence. Enzyme concentration was determined from Bradford assays. Since the Bradford assay using BSA as the standard overestimated the actual protein concentration determined by amino acid analysis, results obtained by Bradford were multiplied by 0.7 .

Preparation of substrate. Enzymatic assays were performed as previously described (41). Substrate was prepared from a 45 -mer oligomer containing a single G/U pair at position 21: 5'-AGC TAC CAT GCC TGC ACG AAU TAA GCA ATT CGT AAT CAT GGT CAT-3' and 3'-TGC ATG GTA CGG ACG TGC TT $G$ ATT CGT TAA GCA TTA GTA CCA GTA-5'.

After the U-containing strand was labeled at the $5^{\prime}$ end with $\mathrm{T} 4$ polynucleotide kinase (New England Biolabs) and heated to $70^{\circ} \mathrm{C}$ to inactivate the kinase, the complementary strand was added, and the solution was cooled slowly to room temperature. The ds end-labeled oligomer was then treated with uracil DNA glycosylase in the presence of $\mathrm{NaBH}_{4}$ as described previously (41). The presence of $\mathrm{NaBH}_{4}$ serves to stabilize the abasic site and does not affect enzymatic activity. Upon cleavage with AP endo, the products of the upper strand were a $5^{\prime}-{ }^{32} \mathrm{P}$ labeled 20-mer and an unlabeled 24-mer containing dRP at the $5^{\prime}$ end. The lower strand, which was unlabeled, remained intact. Steady-state assays were performed as previously described (41) in a $5-\mu$ l volume at room temperature for the times indicated. Preliminary time course studies determined appropriate enzyme concentrations and time intervals. Steady-state concentration dependence was measured by using substrate concentrations between 22.5 and 1,006 $\mathrm{nM}$ over 20-s time intervals with 0.07 or $0.1 \mathrm{nM}$ enzyme. The reaction buffer contained $50 \mathrm{mM}$ HEPES-NaOH (pH 7.5), $0.1 \mathrm{mM}$ EDTA, $5 \mathrm{mM} \mathrm{MgCl}$, and $82 \mathrm{mM} \mathrm{NaCl}$. The experiment was repeated four times, with each determination 


\begin{tabular}{|c|c|}
\hline zfAPEXI & MPKRAKKNEEGVDG--_--EADNGTAAAKKEKKGKEPEAPILYEDPPEKLTSKDGRAA 53 \\
\hline & $111111111++111+1$ \\
\hline APEXI & MPKRGKKGAVAEDGDELRTEPEAKKSKTAAKKNDKEAAGEGPALYEDPPDQKTSPSGKPA 60 \\
\hline & 119 \\
\hline fAPEXX & $\begin{array}{l}\text { NMKITSWNVDGLRAWVKKNGLDWVRKEDPDILCLQETKCAEKALPADITGMPEYPHKYWA } 1 \\
+111111111111+1111111++111111111111+1111+++11+11+\end{array}$ \\
\hline APEXI & TLKICSWNVDGLRAWIKKKGLDWVKEEAPDILCLQETKCSENKLPAELQELPGLSHQYWS 120 \\
\hline & 128 \\
\hline fAPEX1 & $\begin{array}{l}\text { GSEDKEGYSGVAMLCKTEPLNVTYGIGKEEHDKEGRVITAEFPDFFLVTAYVPNASRGLV } 173 \\
\qquad 11111111+1+111+1111+1111+1111111111111111111111\end{array}$ \\
\hline APEX1 & APSDKEGYSGVGLLSRQCPLKVSYGIGEEEHDQEGRVIVAEFDSFVLVTAYVPNAGRGLV 180 \\
\hline & 203205 \\
\hline fAPEX1 & RLDYRKTWDVDFRAYLCGLDARKPLVLCGDLNVAHQEIDLKNPKGNRKNAGFTPEEREGF 233 \\
\hline & $11+11+11 \quad 11+111+11111111111111111111+11111111111111+11+11$ \\
\hline APEXI & RLEYRQRWDEAFRKFLKGLASRKPLVLCGDLNVAHEEIDLRNPKGNKKNAGFTPQERQGF 240 \\
\hline & 261210212 \\
\hline aAPEX1 & TQLLEA-GFTDSFRELYPDQAYAYTFWTYMHNARSKNVGWRLDYFVLSSALLPGLCDSKI 292 \\
\hline & $+11+1 \quad 1111111+1111111111111111111111111+11+$ \\
\hline hAPEXI & GELLQAVPLADSFRHLYPNTPYAYTFWTYMHNARSKNVGWRLDYFLLSHSLLPALCDSKI 300 \\
\hline & 300301 \\
\hline fAPEXI & RNTAMGSDHCPITLFLAV 310 \\
\hline & $1+1+111$ \\
\hline APEXI & $\begin{array}{l}\text { RSKALGSDHCPITLYLAL } 318 \\
308309\end{array}$ \\
\hline
\end{tabular}

FIG. 1. Sequence comparison of the coding regions of zfAPEX1 and hAPEX1 showing that ZAP1 and HAP1 are highly homologous. Critical conserved residues at the active site, as well as Cys $^{65}$ (human), are highlighted.

performed in duplicate. Reactions were terminated by the addition of $0.5 \mathrm{M}$ EDTA to a final concentration of $87 \mathrm{mM}$. Substrate and product were resolved by denaturing polyacrylamide gel electrophoresis (PAGE) using $15 \%$ gel in the presence of $8 \mathrm{M}$ urea. The distribution of isotope was determined by phosphorimager analysis using a Storm 840 PhosphorImager and ImageQuant software (Molecular Dynamics, Sunnyvale, CA).

Design of MOs and preparation of rescue mRNA. The sequences of MOs were designed by the manufacturer (Gene-Tools, LLC, Philomath, OR) as follows: MO1 (5-CAT ATC TTT CTT ACC CAA CAC TTT A), MO2 (5-AAC AAT GCA CTG TTA CCA GTT CCA T), MO3 (5-CGA ATG TGT TCT TAC ATC AAG TCC G), and TS-MO (5-GTT CTT CTT GGC TCT TTT GGG CAT G). The MOs were diluted to $0.25 \mathrm{mM}$ in water, and approximately 1 to $3 \mathrm{nl}$ per embryo was microinjected at the one- to two-cell stage (1-2 cell stage). Microinjection of distilled $\mathrm{H}_{2} \mathrm{O}$ served as the control in each experiment. Each experiment was repeated two to three times. Since different preparations of MO showed slight differences in ability to affect embryonic progression, it was necessary to titrate each batch.

To construct the expression vectors, the encoding regions of hAPEX1 and zfAPEX1 were cloned into the EcoRI and Xhol sites of pCS2+ and sequenced. The $5^{\prime}$ end of the human sequence differed sufficiently from that of the zebra fish sequence that it was not recognized by the TS-MO directed against the zebra fish gene. Furthermore, it could not bind the MOs that target splice sites originating from zfAPEX1a. Template plasmid was linearized with XhoI restriction enzyme, and hAPEX1 mRNA was transcribed using SP6 RNA polymerase (Message Machine; Ambion, Inc., Austin, TX) according to the manufacturer's instructions. Capped mRNAs were purified by phenol-chloroform extraction, dissolved in RNase-free water (Ambion), quantified by UV absorbance, and injected into 1-2 cell stage embryos mixed with the appropriate MO as indicated.

Zebra fish embryo protein extraction. Embryos were homogenized in $200 \mu \mathrm{l}$ of ice-cold radioimmunoprecipitation assay buffer $(1 \times$ phosphate-buffered saline [PBS], $1 \%$ Nonidet P-40, $0.5 \%$ sodium deoxycholate, $0.1 \%$ SDS) containing aprotinin $(2 \mu \mathrm{g} / \mathrm{ml})$, leupeptin $(2 \mu \mathrm{g} / \mathrm{ml})$, pepstatin A $(1 \mu \mathrm{g} / \mathrm{ml})$, and Complete, Mini, EDTA-free protease inhibitor cocktail tablets (one tablet/7 ml) (Roche Diagnostics, Mannheim, Germany). After homogenization, phenylmethylsulfonyl fluoride $(1.3 \mathrm{mg} / \mathrm{ml}$ in $100 \%$ ethanol) was added to the tissue suspensions. After incubation on ice for $30 \mathrm{~min}$, the protein suspension was centrifuged at
$13,000 \mathrm{rpm}$ for $20 \mathrm{~min}$ at $4^{\circ} \mathrm{C}$. The supernatant fraction was carefully removed and microfuged once more. Protein concentrations in the final supernatant fractions were determined via the Bradford assay (Bio-Rad, Hercules, CA) using BSA as the standard. To obtain protein per fish or embryo, total protein extracted was divided by the number of fish or embryos used to prepare the extract.

Western blotting of adult zebra fish and embryo protein extract. Zebra fish embryo and adult protein extracts $(40$ or $80 \mu \mathrm{g}$ ) were resolved on NuPAGE 4 to $12 \%$ bis-Tris SDS-polyacrylamide gels (Invitrogen/Life Technologies) at $200 \mathrm{~V}$ for approximately $2.25 \mathrm{~h}$. The resolved gel products were then either stained with Coomassie blue or transferred to a polyvinyl difluoride (PVDF) membrane (Invitrogen/Life Technologies) by an X Cell II blot module (Invitrogen/Life Technologies). The transfer was performed in NuPAGE transfer buffer (Invitrogen/Life Technologies) at $30 \mathrm{~V}$ for $1 \mathrm{~h}$ at room temperature. After transfer, the membrane was incubated in $1 \times$ PBST $(1 \times$ PBS, $1 \%$ Tween 20$)$ and $5 \%$ nonfat dry milk overnight at $4^{\circ} \mathrm{C}$. After blocking, the membrane was incubated with primary antibody $(1: 2,000)$ for $2.5 \mathrm{~h}$ in $1 \times$ PBST and $5 \%$ nonfat dry milk. Secondary antibody (goat anti-rabbit immunoglobulin G-horseradish peroxidase conjugate; Sigma Chemical, St. Louis, MO) incubation was performed at a 1:3,000 dilution in $1 \times$ PBST and $5 \%$ nonfat dry milk for $1.5 \mathrm{~h}$. The membrane was then washed eight times in $1 \times$ PBST to remove excess secondary antibody (using the washing scheme described above). The hybridized membrane was then exposed to chemiluminescence reagent (NEN Life Science Products, Boston, MA) for $1 \mathrm{~min}$ and exposed to X-ray film. Initially, a wide range of the same peptides used to generate antiserum 2 was dotted onto the same PVDF membrane. This served to calibrate the intensity of the chemiluminescence arising from the ZAP1 band. In later experiments, a narrower range of peptides was used.

Microscopic examination. Live embryos were photographed using Nomarski or fluorescence optics at the W. M. Keck Center, Northeastern University. For acridine orange staining, dechorionated embryos were incubated in $5 \mu \mathrm{g}$ of acridine orange (Sigma Chemical)/ml in E3 medium for $30 \mathrm{~min}$ and analyzed by fluorescence microscopy.

For histological examination, embryos were fixed in $4 \%$ paraformaldehyde, $0.02 \mathrm{M}$ sodium phosphate $(\mathrm{pH} 7.3), 0.15 \mathrm{M} \mathrm{CaCl}_{2}$, and $4 \%$ sucrose. After embedding in paraffin and sectioning, the embryos were stained with hematoxylin-eosin (H\&E) and examined by light microscopy. 
A

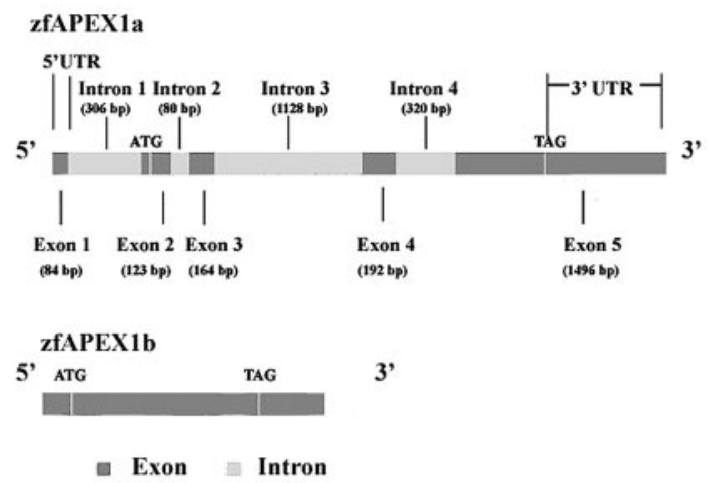

C



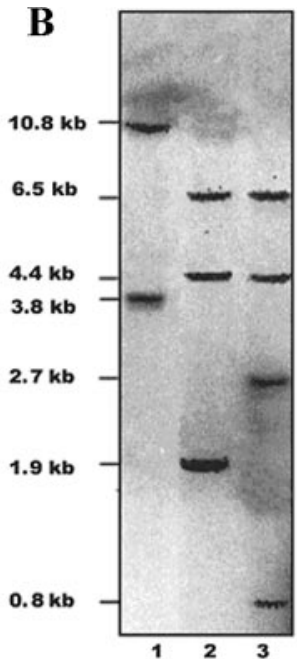



D

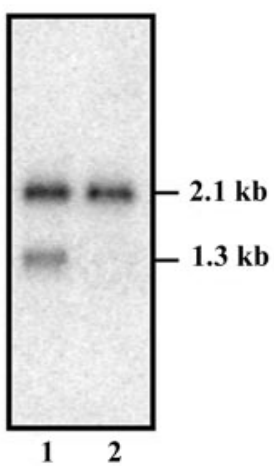

FIG. 2. The zebra fish genome has two copies of the APEX1 gene and two species of mRNA. (A) Diagram of zfAPEX1a and zfAPEX1b. Two copies of zfAPEX1 were identified by genomic PCR, followed by sequencing of the genes. zfAPEX1a contains introns and an extended 3'UTR, whereas zfAPEX1b lacks introns and the $3^{\prime}$ terminus of the $3^{\prime}$ UTR. The coding sequence is identical. (B) Southern blot analysis of zebra fish genomic DNA confirms the presence of two copies of zfAPEX1. DNA extracted from adult fish was treated with NdeI (lane 1), NdeI and EcoRV (lane 2), or HindIII (lane 3) and resolved by agarose gel electrophoresis by means of a 1.5\% gel. After blotting and denaturation, the membrane was probed with full-length cDNA. The diagram to the right shows the location of the NdeI, EcoRV, and HindIII sites in APEX1a. Note that APEX1b has no EcoRV or HindIII sites. (C) Diagram showing the alignment of the two mRNA species for ZAP1. mRNA species were obtained by RT-PCR as described in Materials and Methods and sequenced. (D) Northern blots of mRNA prepared from adult fish. Fish were probed either with full-length cDNA (lane 1) or a 207-bp fragment from the 3'UTR of zfAPEX1a (lane 2). The full-length cDNA probe identified both mRNA species $\left(2,100\right.$ and 1,400 bp in length), whereas the probe from the $3^{\prime}$ UTR identified only the larger mRNA species.

\section{RESULTS}

The cDNA for zebra fish AP endo 1 has a coding sequence for a protein with $\mathbf{3 1 0}$ amino acids and a very high degree of homology (78\%) to mammalian AP endo 1. In initial experiments comparing hAPEX1 with the University of Washington Genome Resources Zebrafish EST database (http://zfish.wustl .edu), we identified one EST (fc54d10.y1) with homology to hAPEX1 when translated to the protein sequence. Primers designed to isolate the sequence of EST fc54d10.y1 were used to amplify a 348-bp fragment from whole zebra fish genomic DNA by PCR, and the fragment was subcloned. This fragment was then used to screen an embryonic zebra fish cDNA library at $8 \mathrm{~h}$ postfertilization (hpf) cloned into pSPORT1 for the presence of a full-length APEX1 gene. The resulting clones fell into two classes: clone 1 was 1,844 bp long, whereas clone 2 was 2,101 bp long. The 933-bp (310 amino acids) coding region of the two clones was identical. The region of divergence was in the $3^{\prime} \mathrm{UTR}$, where clone 2 contained an additional $300 \mathrm{bp}$.
Clone 2 also contained a palindromic repeat in the $3^{\prime}$ UTR between bp 1805 and 1837, which was lacking in clone 1 . The zebra fish protein (ZAP1) was $78 \%$ homologous (67\% identical) with the 318-amino-acid sequence of HAP1, with conservation of all residues involved in endonuclease binding and catalysis (Fig. 1). Note that the residue in the human enzyme that is reported to be required for redox activity, Cys ${ }^{65}$ (48), was not conserved. Depending on the alignment, this residue was replaced in ZAP1 by either a serine $\left(\mathrm{Ser}^{59}\right)$ or a threonine $\left(\mathrm{Thr}^{58}\right)$. Based upon molecular modeling (35), the region with the greatest divergence was in the amino terminus, residues 1 through 40. The three-dimensional structure was very similar (99\%) to that of HAP1 (data not shown).

The genome of zebra fish contains two copies of a gene for an enzyme highly homologous to hAPEX1. (Fig. 2A). Two copies of zfAPEX1 were identified in the zebra fish genome by means of genomic PCR. The longer copy, zfAPEX1a, consisted of four introns (ranging from 80 to $1,128 \mathrm{bp}$ ) and five 
$\mathbf{A}$



B



FIG. 3. Purification and analysis of recombinant ZAP1 reveals a protein with kinetic parameters similar to those of the human protein. (A) PAGE analysis of purified ZAP1. ZAP1 was expressed and purified as described in Materials and Methods. SDS-PAGE reveals a single band. As in the case of the human protein, the zebra fish protein has a slightly slower mobility versus the standard molecular mass markers than is warranted by its size. (B) Lineweaver-Burk plot of ZAP1 endonuclease activity. The assay was performed as described by Strauss et al. (41) between 40 and $1,000 \mathrm{nM}$ substrate, whereas the concentration of enzyme was maintained at $0.07 \mathrm{nM}$. The assay interval was $20 \mathrm{~s}$, during which no more than $5 \%$ of substrate was converted to product. Substrate and product were resolved by denaturing gel electrophoresis (15\% gel) in the presence of $8 \mathrm{M}$ urea. This plot shows the average of four independent experiments.

exons, the first of which was untranslated. Boundaries between exons and introns followed the GT/AG rule. The introns and exons of zfAPEX1a were located in approximately the same position as those in hAPEX1. The zfAPEX1a locus was mapped to zebra fish chromosome 4 according to the Sanger zebra fish whole-genome database. The shorter copy (zfAPEX1b) was identical to the cDNA except that the $3^{\prime}$ and $5^{\prime}$ UTRs were shorter and the gene contained no introns. The map position of zfAPEX1b is unknown at this time. The DNA sequence upstream of both copies of zfAPEX1 lacked a Kozak sequence and other identifiable regulatory sites, including a TATA box, a finding consistent with constitutive expression.

The coding region of zfAPEX1 was gel purified, radiolabeled, and used to probe Southern blots of whole zebra fish genomic DNA. PhosphorImager analysis of the membrane revealed multiple discrete bands in each of three digests (Fig. 2B). The NdeI digest (Fig. 2B, lane 1) contained two bands of approximately 3.9 and $10.8 \mathrm{~kb}$. Three bands $(6.5,4.4$, and 1.8 $\mathrm{kb}$ ) were identified in the EcoRV/NdeI double digest (Fig. 2B, lane 2). The density of the band at $1.8 \mathrm{~kb}$ made it likely that there were two fragments at this molecular size. The third digest with HindIII/NdeI (lane 3) gave evidence of four discrete bands at $6.4,4.3,2.7$, and $0.8 \mathrm{~kb}$. The diagram to the right in Fig. 2B shows the locations in zfAPEX1a of the NdeI, HindIII, and EcoRV sites obtained by genomic sequencing. Note that zfAPEX1b lacked HindIII and EcoRV sites. These data provide evidence that the zebra fish genome contained two copies of the zfAPEX1 gene.

There are two transcripts of zfAPEX1 (Fig. 2C and D). After we performed 5' and 3' RACE with appropriate internal primers to anchor the fragments in the zfAPEX1 gene, we obtained two fragments, which were subcloned and sequenced (Fig. 2C).
Both contained the same coding region for ZAP1 and identical $3^{\prime}$ and $5^{\prime}$ flanking regions. However, the longer sequence contained an additional $707 \mathrm{bp}$ at the $3^{\prime}$ end preceding the poly(A) tail and an additional $67 \mathrm{bp}$ at the $5^{\prime}$ end. To confirm this observation, we performed Northern blot analysis (Fig. 2D) with two different probes. When the coding region was used as the probe, we observed two bands at 2.1 and $1.3 \mathrm{~kb}$, respectively. However, when we used the 297-bp sequence from the longer $3^{\prime}$ end as a probe, there was only a single 2.1-kb band (Fig. 2D, lane 2). The result confirmed that the larger transcript is the one containing the unique sequence from zfAPEX1a.

zfAPEX1 encodes a protein that cleaves an abasic site $\mathbf{5}^{\prime}$ to the dRP. The calculated molecular mass of ZAP1 is $34.8 \mathrm{kDa}$. PAGE analysis of the purified, recombinant protein (Fig. 3A) revealed a single protein band with an approximate molecular mass of $36.7 \mathrm{kDa}$. Like the human protein, the zebra fish protein had a slightly slower mobility than the standard molecular than markers than was warranted by its amino acid sequence. Amino-terminal sequencing of the purified protein confirmed the expected sequence. Amino acid analysis revealed that a Bradford assay with BSA as the standard overestimated the amount of protein by $30 \%$. This effect is also seen with the human protein (41). The $K_{m}$ for the zebra fish protein was $100 \mathrm{nM}$, and the $V_{\text {max }}$ was $32 \mathrm{fmol} / 20 \mathrm{~s}$ when enzyme was present at $0.07 \mathrm{nM}$ (Fig. 3B). Therefore, the turnover number for ZAP1 was $4 \mathrm{~s}^{-1}$, in excellent agreement with that of HAP1 (41). Like the human protein, ZAP1 also had a $3^{\prime}$ exonuclease activity at ca. $1 \%$ the level of its endonuclease activity.

zAPEX1 mRNA is expressed throughout embryogenesis. In situ hybridization using the full-length transcript of the cDNA as the probe indicated that zfAPEX1 was heavily expressed in 


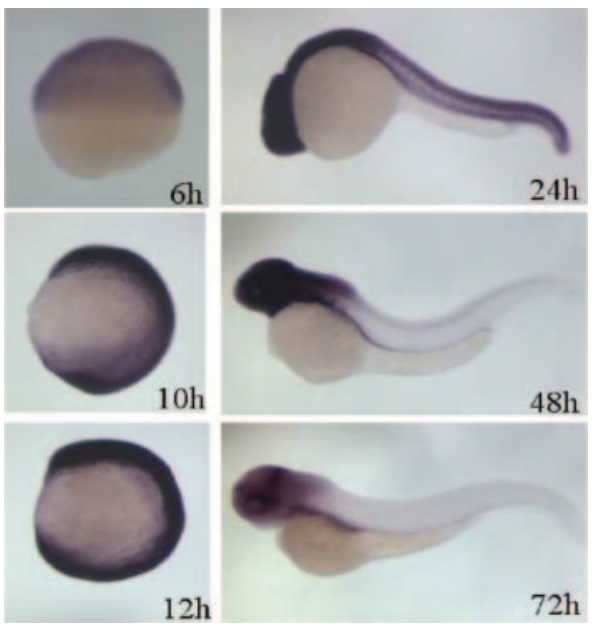

FIG. 4. zfAPEX1, expressed throughout development, is a maternal protein. Embryos at different stages were probed by in situ hybridization, using full-length transcript of the zfAPEX1 cDNA. mRNA is found throughout the embryo at all stages, although at later stages it is more heavily expressed in the head region. Note the density of stain in the cardiac region at 48 and $72 \mathrm{hpf}$.

the early stages of embryogenesis (Fig. 4). By 48 hpf, relatively less message was found in the tail region and relatively more was found in the head region. Thus, ZAP1 fell into the class of genes that are transcribed before the midblastula transition (MBT). We confirmed this finding by using RT-PCR of RNA transcripts obtained as early as $2 \mathrm{hpf}$ (data not shown).

We also examined the protein content of ZAP1 at different stages of development (Fig. 5, top panel). Protein extracts were prepared from unfertilized eggs, from embryos at two stages of development, and from adult fish. Since antibody to the human protein failed to recognize ZAP1, we prepared several antisera predicted to be on the protein surface by homology modeling with HAP1. Antiserum 2, prepared against peptide 140-155, recognized a $36.6-\mathrm{kDa}$ band in protein extracts from all four developmental stages (Fig. 5, top right panel). The signal was blocked when antiserum was mixed with free peptide epitope. This antiserum also recognized purified recombinant ZAP1, as well as HAP1. Density quantification indicated the highest concentration of this protein, 105 pmol per fish, occurred in the adult zebra fish. The amount of protein per cell, however, decreased as development progressed: each egg had approximately 600 fmol of AP endo, whereas $50 \%$ epiboly embryos had $5 \times 10^{-3} \mathrm{fmol} / \mathrm{cell}\left(\sim 10^{5}\right.$ cells $/ 50 \%$ epiboly embryo) (24). Since the number of cells at $24 \mathrm{hpf}$ and in adult fish is apparently unknown, this calculation could not be performed for older embryos and adults. However, since cell numbers continued to increase during development by many orders of magnitude, whereas the amount of ZAP1 protein per organism increased $\sim 100$-fold, we concluded that AP endo is present in the highest concentration in the unfertilized egg and, therefore, is a maternal protein.

Functional zfAPEX1 mRNA is required for early development. We then examined the effects of knockdown by microinjecting MOs directed at different parts of the zfAPEX1 gene (Table 1). Microinjection of 20 embryos each with $\sim 3 \mathrm{ng}$ of MO directed at the translation start site of the gene (TS-MO)


FIG. 5. Quantification of ZAP1 by Western blot analysis. (Top) ZAP1 is found at all stages of development. Cell extract was prepared in the presence of protease inhibitors from unfertilized eggs (lane 1), $50 \%$ epiboly embryos (lane 2), 24-hpf embryos (lane 3), and adults (lane 4). Protein was quantitated by Bradford assay. Proteins $(80 \mu \mathrm{g})$ in each extract was resolved by SDS-PAGE and either stained with Coomassie blue (left panel) or transferred to PVDF membranes for probing with rabbit antiZAP1 antibody 2 (right panels). Various concentrations of the same peptide epitope used for antiserum generation, dotted onto PVDF membranes, were used to calculate the amount of ZAP1 in each lane. Controls containing the peptide to which the antibody was prepared blocked binding (not shown). (Bottom) Quantification of ZAP1 after knockdown and rescue reveals that too little or too much protein is deleterious to development. Embryos were microinjected with $\mathrm{H}_{2} \mathrm{O}$ (lane 1), $0.75 \mathrm{pmol}$ of TS-MO (lane 2), 0.45 pmol of TS-MO (lane 3 ), or $0.75 \mathrm{pmol}$ of TS-MO along with $0.3 \mathrm{ng}$ of mRNA for hAPEX1 (lane 4) and collected at $6 \mathrm{hpf}$. Then, $40 \mu \mathrm{g}$ from each protein extract was resolved by SDS-PAGE and either stained with Coomassie blue (left panel) or transferred to membranes for Western blotting with antiserum 2 (right panel). The expressed protein is present at $20 \%$ of the level of controls in knockdowns (lane 2), $78 \%$ of the level of controls in hypomorphs (lane 3), and 220\% of the level of control in embryos rescued with mRNA for hAPEX1 (lane 4).

resulted in 20 of 20 dead embryos within $24 \mathrm{hpf}$. In a second experiment, microinjection of $1.5 \mathrm{ng}(0.75 \mathrm{pmol} / \mathrm{embryo})$ of TS-MO resulted in death that was clearly visible by $5.5 \mathrm{hpf}$ with the embryo remaining at the MBT (Table 1, condition 1, and Fig. 6A and B). The MBT is closely analogous to the embryonic day 5.5 stage of mouse embryogenesis (http://genex.hgu .mrc.ac.uk), the stage at which Xanthoudakis et al. (55) reported that murine knockouts die.

To assess the effectiveness of the TS-MO in knocking down 
TABLE 1. Knockdown and rescue of zfAPEX1 illustrates the importance of AP endo in development ${ }^{a}$

\begin{tabular}{|c|c|c|c|c|c|c|}
\hline \multirow{2}{*}{$\begin{array}{l}\text { Exptl } \\
\text { condition }\end{array}$} & \multicolumn{3}{|c|}{ Amt of material microinjected } & \multicolumn{3}{|c|}{$\%$ with morphology (SD, no. of expts) ${ }^{b}$} \\
\hline & TS-MO (pmol) & Rescue mRNA (ng) & SS-MO (pmol) & MBT block & Normal & $\begin{array}{c}\text { Abnormal heart } \\
\text { development }\end{array}$ \\
\hline 1 & 0.75 & & & $99(1,10)$ & $0.3(0.2,10)$ & $0(0,10)$ \\
\hline 2 & & & MO1 (1.5) & $3(1,3)$ & $97(1,3)$ & $0(0,3)$ \\
\hline 3 & & hAPEX1 (WT) (0.3) & & $2(1,3)$ & $98(0.2,3)$ & $0(0,3)$ \\
\hline 4 & 0.75 & hAPEX1 (WT) (0.3) & & $40(2,4)$ & $2(0.2,4)$ & $60(3,4)$ \\
\hline 5 & 0.75 & hAPEX1 Y171F (0.3) & & $90(3,3)$ & $8(3,3)$ & $1(0.5,3)$ \\
\hline 6 & & & MO1 to $-3(1.5)$ & $10(4,4)$ & $40(6,4)$ & $49(2,4)$ \\
\hline 7 & & zfAPEX1 (WT) (1) & & $21(3,3)$ & $49(3,3)$ & $32(3,3)$ \\
\hline 8 & 0.45 & & & $53(3,3)$ & $0.5(0.1,3)$ & $42(4,3)$ \\
\hline 9 & Water & & & $3(1,10)$ & $97(1,10)$ & $0(0,10)$ \\
\hline
\end{tabular}

${ }^{a}$ Embryos were injected with the indicated MO, RNA, or water and examined microscopically at the indicated stage. WT, wild type.

${ }^{b}$ The data are percentages from 3 to 10 experiments. Each group contained 46 to 173 embryos. The numbers in parentheses are the standard deviation, followed by the number of independent trials.

zfAPEX1, we examined whether microinjection of the TS-MO or the mRNA for hAPEX1 by itself altered the concentration of ZAP1 protein by Western blot analysis (Fig. 5B and 6C). Microinjection of 0.75 pmol TS-MO/embryo resulted in 80 to $90 \%$ depletion of ZAP1 protein at $6 \mathrm{hpf}$ (compare Fig. 5, lower panel, lanes 1 and 2, and Fig. 6C, lanes 1 and 2). Knockdown to this level could only occur when the translation of both gene copies was blocked in embryos that received the TS-MO. Microinjection of rescue mRNA by itself did not alter the amount of ZAP1 protein relative to that of untreated embryos (Fig. 6C, lane 3).

Knockdown using MO directed at the first, second, and third intron/exon junctions (SS-MO) or lower concentrations of TS-MO results in a lethal phenotype involving the heart, notochord, eyes, brain, and erythrocytes. Because there were two copies of zfAPEX1, where one copy lacked introns, we designed MOs against the splice sites of zfAPEX1a to examine whether differential knockdown might provide additional insights. Microinjection of a single SS-MO directed against the first splice site had no effect on development (Table 1, condition 2). However, knockdown with SS-MOs directed against the first three splice sites (total MO concentration $=1.5 \mathrm{pmol} /$ embryo) or all four splice sites (total $\mathrm{MO}$ concentration $=1.5$ $\mathrm{pmol} / \mathrm{embryo}$ ) resulted in the appearance of a characteristic phenotype with dysmorphic hearts, pericardial edema, small eyes, brain abnormalities, and crooked tails (Table 1, condition 6, and Fig. 6D to M). We also obtained the same results when we microinjected lower concentrations of TS-MO ( 0.4 to 0.5 $\mathrm{pmol} / \mathrm{embryo}$ ). Although it was easy to see erythrocytes moving along the vertebral arteries of live normal fish by Nomarski optics at 3 days postfertilization (dpf), we were unable to visualize blood flow in hypomorphs. Pericardial edema was already visible at $2 \mathrm{dpf}$ and frequently massive thereafter. Cross-sections through the pericardial sac confirmed the presence of large amounts of fluid and abnormal heart structure (Fig. 6D to $\mathrm{H}$ ). Although we identified the heart cushion between the two chambers (Fig. 6I), the walls of both chambers were a single cell thick, and no blood vessels were ever identified associated with the heart.

Hearts of MO-injected embryos failed to complete looping and remained central and linear (compare Fig. 6D [hypomorph] with Fig. 6E [control]). To image normal and defective hearts more fully, we performed knockdown experiments on transgenic fish (cmlc2:GFP) carrying the gene for cardiac myosin coupled to green fluorescent protein (4). The distribution of cmlc2:GFP allowed us to identify a range of looping defects in hypomorphs, obtained either as rescues with mRNA for hAPEX1 or as partial knockdowns with lower concentrations of TS-MO. Defects ranged from complete looping failure (Fig. $6 \mathrm{G}$, linear heart tube) to partial failure (Fig. 6F, heart tube with a bulge). A normal heart, shown in Fig. $6 \mathrm{H}$, illustrated the asymmetric distribution of cmlc2:GFP in the atrium and ventricle from normal embryos of this transgenic strain (4). These experiments were particularly noteworthy because they demonstrate that failure to loop occurred even though cardiac myosin was synthesized. In line with the presence of cardiac myosin in hypomorph hearts, we observed cardiac contraction in hypomorphs. However, the heartbeats of SS-MO-injected embryos were slower and erratic in comparison with those of their control, $\mathrm{H}_{2} \mathrm{O}$-injected siblings (Table 2).

In addition to abnormal heart development, MO-injected embryos had disorganized eye buds in a uniform pattern, with few cells in the outer layers (Fig. 6J). The brain tissue was disorganized and much smaller, particularly in the midbrain section (Fig. 6J), with many structures apparently filled with fluid. Erythrocytes were very difficult to identify in stained sections of MO-injected hypomorphs (compare circled areas in Fig. 6L and M).

Apoptosis does not occur in embryos halted at the MBT but is enhanced in hypomorphs at $\mathbf{3 0} \mathbf{~ h p f}$. Using acridine orange, a membrane-permeable aromatic derivative that fluoresces in acidic lysosomal vesicles, we demonstrated severe apoptosis in the foreheads, midbrains, and tails of hypomorphs that had received SS-MO or lower concentrations ( 0.1 to $0.5 \mathrm{pmol} /$ embryo) of TS-MO at $30 \mathrm{hpf}$ (Fig. 6Q). Embryos that had been microinjected with TS-MO and failed to progress beyond the MBT did not manifest apoptosis. (Compare the water-injected controls in Fig. $6 \mathrm{~N}$ with the TS-MO-injected embryos in Fig. 6O.) Therefore, apoptosis was not required for failure of embryos to progress when ZAP1 was depleted.

Morphants that fail to progress beyond the MBT can be rescued. Coinjection of human mRNA for wild-type hAPEX1 enabled more than half of the hypomorphs to pass the MBT (Table 1, condition 4). However, most of the hypomorphs had a phenotype similar to that of the embryos that had been injected with SS-MO or a lower concentration of TS-MO. 

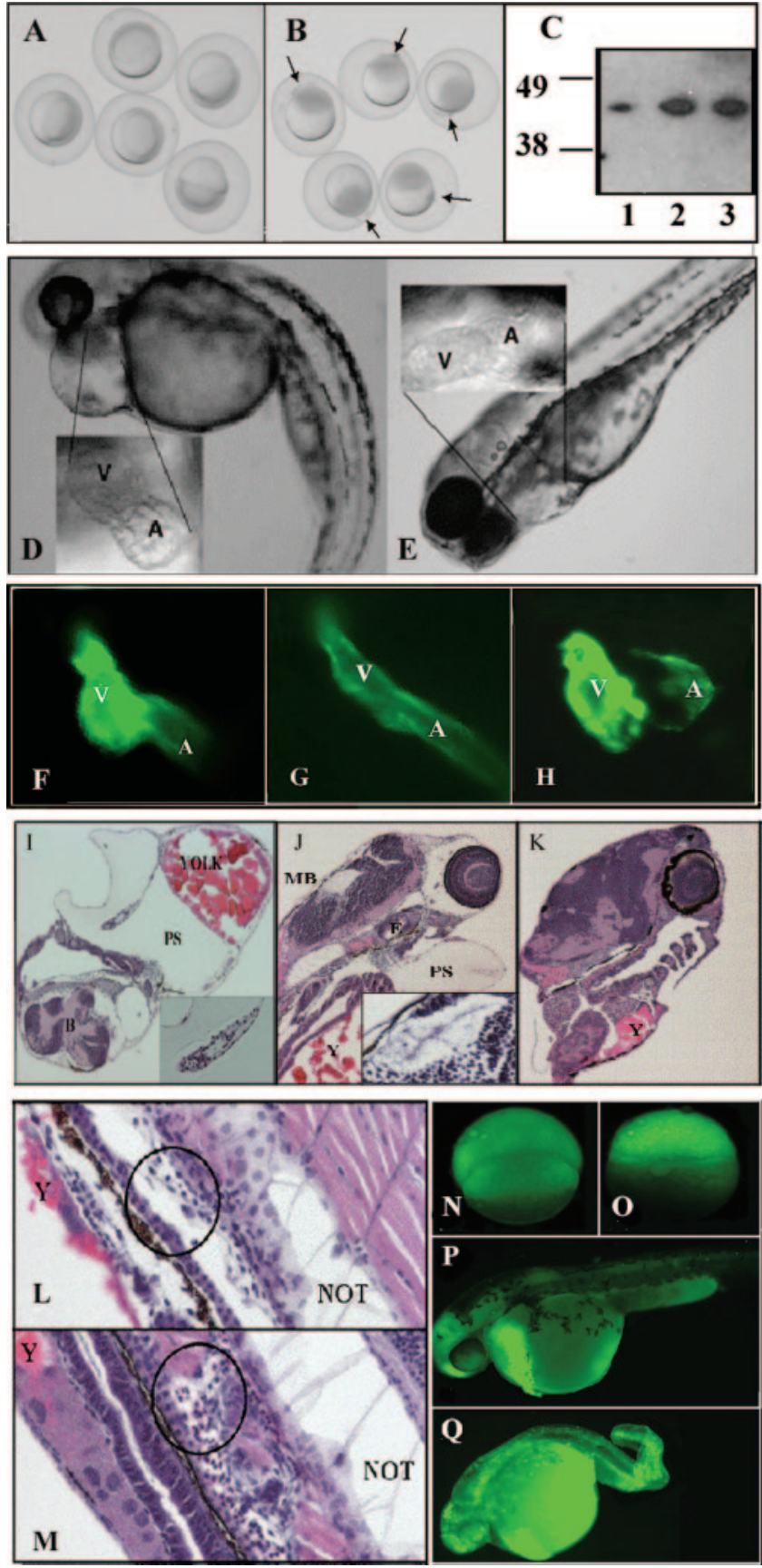

FIG. 6. Microscopic examination reveals an array of abnormalities in knockdown embryos and in hypomorphs. (A and B) Death occurs shortly after the MBT, when expression of both gene copies is blocked. Embryos were injected with $1.5 \mathrm{ng}(0.75 \mathrm{pmol})$ of a random $\mathrm{MO}(\mathrm{A})$ or the TS-MO zfAPEX1 (B) and monitored for developmental progress. Note the disordered appearance of parts of the embryonic cap (arrows) in panel B. These embryos will not progress further. See also panels $\mathrm{N}$ (injected with water) and $\mathrm{O}$ (knockdown) for lack of apoptosis as shown by the absence of acridine orange uptake. (C) Diminution of AP endo protein by microinjection of TS-MO. Embryos were microinjected at the $1-2$ cell stage with $0.75 \mathrm{pmol}$ of TS-MO (lane 1), $1 \mathrm{ng}$ of zfAPEX1 mRNA (lane 2), or $3 \mathrm{nl}$ of water (lane 3). Protein extracts were prepared at $6 \mathrm{hpf}$ and resolved by SDS-PAGE. Each lane contained $80 \mu \mathrm{g}$ of protein. The Western blot was probed with polyclonal rabbit anti-ZAP1 antibody 2. (D and E) Cardiac abnormalities in embryos injected with MO directed against the four splice sites of zfAPEX1. Live fish, injected with 1.5 pmol SS-MO (D) or water (E), were
TABLE 2. SS-MO hypomorphs with abnormal hearts have slowed heartbeats ${ }^{a}$

\begin{tabular}{cccc}
\hline \multirow{2}{*}{ Age (hpf) } & \multicolumn{2}{c}{$\begin{array}{c}\text { Avg no. of heartbeats/min } \\
\text { (SD) }\end{array}$} & $\begin{array}{c}\text { \% of control (SD, no. of } \\
\text { independent trials) }\end{array}$ \\
\cline { 2 - 3 } & MO injected & Control & \\
\hline 48 & $90(8)$ & $155(15)$ & $60(1,3)$ \\
72 & $95(6)$ & $170(15)$ & $57(8,3)$ \\
\hline
\end{tabular}

${ }^{a}$ Embryos were injected with $1.5 \mathrm{pmol}$ of SS-MO directed against splice sites 1 to 3 and examined microscopically at 48 or $72 \mathrm{hpf}$. These data are averages of measurements from 10 embryos in each group. The heartbeat rate was determined three times for each embryo.

Microinjection of zfAPEX1 mRNA alone resulted in failure to pass the MBT for $21 \%$ of embryos, whereas $32 \%$ had abnormal cardiac development (Table 1, condition 7), even though the concentration of ZAP1 remained unchanged (Fig. 5C). Mutant hAPEX1 defective in endonuclease activity (Y171F) was unable to rescue (embryos in which ZAP1 had been fully knocked down) (Table 1, condition 5). Therefore, the endonuclease activity of ZAP1 was required for successful passage through the MBT.

Quantitation of AP endo protein after knockdown and rescue reveals the importance of the maintenance of correct protein levels. We used Western blot analysis to examine the amount of AP endo present in hypomorphs (Fig. 5B). Protein extracts were prepared from 6-hpf embryos microinjected with $\mathrm{H}_{2} \mathrm{O}$ (controls), 0.75 pmol of TS-MO (knock-down), $0.45 \mathrm{pmol}$ of TS-MO (hypomorph), or 0.75 pmol of TS-MO, along with

examined by Nomarski microscopy at $5 \mathrm{dpf}$. The movement of red cells through the vertebral artery was easily observed in controls but not in hypomorphs. Note the enlarged pericardial sac, linear abnormal heart, small eyes, and body curvature visible in the hypomorph. The insets show high-resolution images of the heart region. A, atrium; V, ventricle. ( $\mathrm{F}$ to $\mathrm{H}$ ) cmlc2:GFP fish reveal a range of abnormalities in hypomorph hearts. cmlc2:GFP fish were microinjected with 0.45 pmol TSMo/embryo or water and examined at $90 \mathrm{hpf}$. The hearts of two different hypomorphs ( $F$ and $G$ ) show the range of cardiac defects visible at 90 hpf. A normal heart is shown in panel H. (I) Cross-section through the heart of a 5-dpf embryo knocked down with 1.5 pmol SS-MO reveals two rudimentary chambers with walls that are a single cell thick and the presence of a cushion. Stain, H\&E. YOLK, yolk sac; PS, pericardial sac; B, brain. The inset image is a higher magnification of the same section. ( $\mathrm{J}$ and $\mathrm{K}$ ) Cross-sections through the head and midbrain of a normal and hypomorphic embryo reveal abnormal eyes and brain structure. (J) An embryo at 5 dpf knocked down with SS-MO or $(\mathrm{K})$ mock injected with water. Note the area surrounding the eye and the midbrain with few cells. The inset shows a higher-magnification view of the midbrain of the hypomorph. Stain, H\&E. (L and M) Cross-section through the notochord, vertebral artery, and gut of normal and hypomorph embryos knocked down with SS-MO. Embryos were knocked down (L) or mock injected with water (M). Note the absence of red cells in panel L. Y, yolk; NOT, notochord. The vestiges of yolk are red. Stain, H\&E. (N to Q) Death occurs without apoptosis in very early embryos, but abnormal hypomorphs at later stages exhibit enhanced apoptosis. Embryos were microinjected at the 1-2 cell stage with 0.45 pmol of TS-MO (O and $\mathrm{Q})$ or with water $(\mathrm{N}$ and $\mathrm{P})$ and exposed to acridine orange at $4 \mathrm{hpf}(\mathrm{N}$ and $\mathrm{O})$ or $30 \mathrm{hpf}(\mathrm{P}$ and $\mathrm{Q})$. No apoptotic cells are seen in embryos at $4 \mathrm{hpf}$. At $30 \mathrm{hpf}$ apoptosis in normal embryos is restricted to olfactory, hatching glands and liver (8), whereas that in SS-MO-injected embryos is present throughout the embryo, but particularly in the midbrain, tail, and notochord. 
$0.3 \mathrm{ng}$ of mRNA for hAPEX1 (rescue). A total of $40 \mu \mathrm{g}$ from each extract was resolved by SDS-PAGE and either stained with Coomassie blue or transferred for Western blotting with antiserum 2. Coomassie blue staining (left panel) revealed that all major proteins had been synthesized to the same degree under all conditions. Western blot analysis revealed that ZAP1 was reduced by $80 \%$ in knockdowns and by $22 \%$ in hypomorphs. AP endo levels were actually increased to $220 \%$ versus control levels after rescue with mRNA for the human gene.

\section{DISCUSSION}

In this study, we demonstrate for the first time that a wellcharacterized DNA repair protein plays an intimate role in vertebrate development. AP endo is known for its ability to cleave abasic sites generated spontaneously or through oxidative damage as a part of the base excision repair pathway (14). The resulting 3'-hydroxyl group then becomes the substrate for the repair polymerase to insert the correct nucleotide. However, a rationale for the lethal phenotype in knockout mice (7, 55) has been missing. Here we show that full knockdown of AP endo in early zebra fish embryos leads to embryonic failure at the MBT, a stage that corresponds to lethality in mice. In contrast, partial knockdown or rescue of knockdown embryos with mRNA for the human gene enables embryos to survive for up to $7 \mathrm{dpf}$. However, they develop a range of abnormalities in the eyes, notochord, brain, blood cells and, especially, the heart.

Similar to AP endo knockout mice, most bmp4 knockout mice will die at embryonic day 6.5 (54). Bone morphogenetic proteins (Bmps) belong to the transforming growth factor $\beta$ superfamily of proteins that are involved in many aspects of development $(5,6,16,25)$. Tissue-specific inactivation of Bmp4 has revealed roles for development in heart, lens induction, bone, and neural tissue (20). We see analogous effects in zebra fish hypomorphic for ZAP1.

In zebra fish some genes that are multifunctional in mammals have evolved through complementary degenerative mutations (7). Unlike the human genome or the Fugu genome, each with a single copy of APEX1, the zebra fish genome has two copies of zfAPEX1. One copy, zfAPEX1a, matches the general structure of hAPEX1 with introns in similar locations and an extended $3^{\prime} \mathrm{UTR}$. The other copy, zfAPEX1b, has a truncated $3^{\prime}$ UTR and lacks introns. Since the coding sequences are identical but the introns are missing in zfAPEX1b, it is unlikely that complementary degenerative mutation has occurred. Rather, it is more likely that the copy without introns is the result of an event involving a retrotransposon. One other zebra fish gene with two copies where one copy has no introns, $n t l$, has been identified (56).

Not only do zebra fish have two gene copies for AP endo but they also have two mRNA species. The longer copy clearly arises from zfAPEX1a. The shorter copy could be a processed form of zfAPEX1a or it could arise from zfAPEX1b, which has no introns. We believe that both gene copies are utilized, because only when the MO is directed against the translation start site do embryos die at the MBT. In contrast, when MOs are directed simultaneously against three or four splice sites, embryos pass the MBT but die by $7 \mathrm{dpf}$ because of defective cardiac development, among other problems. Taken together, these results imply that both gene copies are transcribed and translated and both are required for normal development.

ZAP1 has $78 \%$ homology (64\% identity) with human AP endo. All residues involved with endonuclease binding and catalysis are conserved $(34,42,44,52)$. When ZAP1 is expressed in a heterologous system, the purified protein has the kinetic characteristics of the HAP1 protein, including the same $K_{m}$ and turnover number. However, the zebra fish equivalent of $\mathrm{Cys}^{65}$, the cysteine residue reportedly required for redox activity in the human protein $(11,48)$, is replaced with serine or threonine, depending on the alignment. Cysteine, serine, and threonine can all serve to stabilize tertiary structure through hydrogen bonding. Therefore, a redox function, at least at this residue, is not required for viability or development to $7 \mathrm{dpf}$. This observation is in agreement with that of Fung and Demple (15), who demonstrated that cells in which hAPEX1 has been knocked down can be rescued with yeast APN1, which has no redox function.

However, rescue of knockdowns in zebra fish fails when the rescuing human mRNA is mutant in $\mathrm{Tyr}^{171}$. Mutation of HAP1 at $\mathrm{Tyr}^{171}$ to phenylalanine or alanine results in a drastic loss in enzymatic efficiency (36) without alteration in the tertiary structure (S. T. Mundle and P. R. Strauss, unpublished data) Therefore, the ability to cleave an abasic site, a major step in the repair of oxidatively damaged DNA, is required for viability and early development.

Most cultured cells containing p53 undergo apoptosis when AP endo levels are decreased below a certain level (B. Demple, unpublished data). In our experiments, we found severe apoptosis at $30 \mathrm{hpf}$ in the midbrains and tails of hypomorphs microinjected with SS-MO or a lower concentration of TS-MO. However, our results show that apoptosis (8) is not necessary for the development to stop. Embryonic progression stops at the MBT or shortly thereafter when expression from both gene copies of zfAPEX1 is knocked down, even though apoptosis is not detected until $8 \mathrm{hpf}(8)$.

The most prominent phenotype seen in hypomorphic embryos is extensive pericardial edema that is most likely secondary to the dysfunctional heart, which fails to complete looping, and accompanied by lack of circulating red cells. Knockdown of three distinct genes in zebra fish, $t b \times 5, h r T$, and fog1, leads to a failure in looping $(18,45,50)$. Of these, only the phenotype of $h r T$ matches the one described here with failure of vascular development, heart looping, and cardiac edema (45). It is unclear at this time whether the defect lies with vasculogenesis (1, $13,31,43)$ or hematopoiesis $(2,3,19,21,28,32)$. All of the affected organs, including the heart primordium, are from the same general area of the mesoderm (46).

Finally, the overexpression of AP endo in embryos also leads to the hypomorphic phenotype. This observation is consistent with studies in mammalian cells, in which overexpression of the protein leads to enhanced apoptosis mediated by p53 (17).

In conclusion, our findings demonstrate unexpected roles for AP endo in embryonic cardiovascular, hematopoietic, neural, and notochord development. Endonuclease function is required. Many pressing questions remain to be explored. The details of how AP endo participates in differentiation are unknown. Furthermore, the present study does not address the rationale for why embryonic progression fails at the MBT without apoptosis in the absence of the protein. Nevertheless, 
our findings further elucidate the function of AP endo. Clearly, further analysis is required to discern the molecular targets and mechanisms underlying the functions of AP endo in cell division and differentiation.

\section{ACKNOWLEDGMENTS}

We thank P. Yelick for providing the zebra fish cDNA library in pSPORT; P. Yelick, H. Sive, and H. Jo for technical expertise and helpful discussions; and $\mathrm{H}$. Sive and Z. Werb for critical reading of the manuscript. We thank C. Geoffrey Burns for providing cmlc2-GFP fish. Nomarski and fluorescence microscopy was performed with the W. M. Keck 3D fusion microscope at Northeastern University's Keck facility.

This study was supported by NIH CA74202, NIH HD053317, and funds from Northeastern University.

\section{REFERENCES}

1. Brown, L. A., A. R. Rodaway, T. F. Schilling, T. Jowett, P. W. Ingham, R. K. Patient, and A. D. Sharrocks. 2000. Insights into early vasculogenesis revealed by expression of the ETS-domain transcription factor Fli-1 in wildtype and mutant zebrafish embryos. Mech. Dev. 90:237-252.

2. Brownlie, A., C. Hersey, A. C. Oates, B. H. Paw, A. M. Falick, H. E. Witkowska, J. Flint, D. Higgs, J. Jessen, N. Bahary, H. Zhu, S. Lin, and L. Zon. 2003. Characterization of embryonic globin genes of the zebrafish. Dev. Biol. 255:48-61.

3. Burns, C. E., D. Traver, E. Mayhall, J. L. Shepard, and L. I. Zon. 2005 Hematopoietic stem cell fate is established by the Notch-Runx pathway. Genes Dev. 19:2331-2342.

4. Burns, C. G., D. J. Milan, E. J. Grande, W. Rottbauer, C. A. MacRae, and M. C. Fishman. 2005. High-throughput assay for small molecules that modulate zebrafish embryonic heart rate. Nat. Chem. Biol. 1:263-264.

5. Chang, C., D. A. Holtzman, S. Chau, T. Chickering, E. A. Woolf, L. M. Holmgren, J. Bodorova, D. P. Gearing, W. E. Holmes, and A. H. Brivanlou. 2001. Twisted gastrulation can function as a BMP antagonist. Nature 410: 483-487.

6. Chang, W., P. ten Dijke, and D. K. Wu. 2002. BMP pathways are involved in otic capsule formation and epithelial-mesenchymal signaling in the developing chicken inner ear. Dev. Biol. 251:380-394.

7. Chen, K. H., F. M. Yakes, D. K. Srivastava, R. K. Singhal, R. W. Sobol, J. K. Horton, B. Van Houten, and S. H. Wilson. 1998. Up-regulation of base excision repair correlates with enhanced protection against a DNA damaging agent in mouse cell lines. Nucleic Acids Res. 26:2001-2007.

8. Cole, L. K., and L. S. Ross. 2001. Apoptosis in the developing zebrafish embryo. Dev. Biol. 240:123-142.

9. David, S. S., and S. D. Williams. 1998. Chemistry of glycosylases and endonucleases involved in base-excision repair. Chem. Rev. 98:1221-1262.

10. Demple, B., T. Herman, and D. S. Chen. 1991. Cloning and expression of APE, the cDNA encoding the major human apurinic endonuclease: definition of a family of DNA repair enzymes. Proc. Natl. Acad. Sci. USA 88 11450-11454.

11. Evans, A. R., M. Limp-Foster, and M. R. Kelley. 2000. Going APE over ref-1. Mutat. Res. 461:83-108.

12. Fan, Z., P. J. Beresford, D. Zhang, Z. Xu, C. D. Novina, A. Yoshida, Y Pommier, and J. Lieberman. 2003. Cleaving the oxidative repair protein Ape1 enhances cell death mediated by granzyme A. Nat. Immunol. 4:145153.

13. Fouquet, B., B. M. Weinstein, F. C. Serluca, and M. C. Fishman. 1997 Vessel patterning in the embryo of the zebra fish: guidance by notochord Dev. Biol. 183:37-48.

14. Friedberg, E. C., G. C. Walker, W. Siede, R. D. Wood, R. A. Schultz, and T. Ellenberger. 2006. DNA repair and mutagenesis, 2nd ed. ASM Press, Washington, D.C.

15. Fung, H., and B. Demple. 2005. A vital role for ape1/ref1 protein in repairing spontaneous DNA damage in human cells. Mol. Cell 17:463-470.

16. Furuta, Y., and B. L. Hogan. 1998. BMP4 is essential for lens induction in the mouse embryo. Genes Dev. 12:3764-3775.

17. Gaiddon, C., N. C. Moorthy, and C. Prives. 1999. Ref-1 regulates the transactivation and proapoptotic functions of p53 in vivo. EMBO J. 18:5609-5621.

18. Garrity, D. M., S. Childs, and M. C. Fishman. 2002. The heartstrings mutation in zebrafish causes heart/fin Tbx5 deficiency syndrome. Developmen 129:4635-4645.

19. Gering, M., A. R. Rodaway, B. Gottgens, R. K. Patient, and A. R. Green 1998. The SCL gene specifies haemangioblast development from early mesoderm. EMBO J. 17:4029-4045.

20. Goldman, D. C., R. Hackenmiller, T. Nakayama, S. Sopory, C. Wong, H. Kulessa, and J. L. Christian. 2006. Mutation of an upstream cleavage site in the BMP4 prodomain leads to tissue-specific loss of activity. Development 133:1933-1942.
21. Hess, J. L., B. D. Yu, B. Li, R. Hanson, and S. J. Korsmeyer. 1997. Defects in yolk sac hematopoiesis in Mll-null embryos. Blood 90:1799-1806.

22. Jayaraman, L., K. G. Murthy, C. Zhu, T. Curran, S. Xanthoudakis, and C. Prives. 1997. Identification of redox/repair protein Ref-1 as a potent activator of p53. Genes Dev. 11:558-570.

23. Kane, C. M., and S. Linn. 1981. Purification and characterization of an apurinic/apyrimidinic endonuclease from HeLa cells. J. Biol. Chem. 256: 3405-3414.

24. Kimmel, C. B., W. W. Ballard, S. R. Kimmel, B. Ullmann, and T. F. Schilling. 1995. Stages of embryonic development of the zebrafish. Dev. Dyn. 203:253310.

25. Kishigami, S., and Y. Mishina. 2005. BMP signaling and early embryonic patterning. Cytokine Growth Factor Rev. 16:265-278.

26. Klinedinst, D. K., and N. R. Drinkwater. 1992. Mutagenesis by apurinic sites in normal and ataxia telangiectasia human lymphoblastoid cells. Mol. Carcinog. 6:32-42.

27. Kubota, Y., R. A. Nash, A. Klungland, P. Schar, D. E. Barnes, and T. Lindahl. 1996. Reconstitution of DNA base excision-repair with purified human proteins: interaction between DNA polymerase beta and the XRCC1 protein. EMBO J. 15:6662-6670.

28. Liang, D., J. R. Chang, A. J. Chin, A. Smith, C. Kelly, E. S. Weinberg, and R. Ge. 2001. The role of vascular endothelial growth factor (VEGF) in vasculogenesis, angiogenesis, and hematopoiesis in zebrafish development. Mech. Dev. 108:29-43.

29. Lindahl, T. 1993. Instability and decay of the primary structure of DNA Nature 362:709-715.

30. Lucas, J. A., Y. Masuda, R. A. Bennett, N. S. Strauss, and P. R. Strauss. 1999. Single-turnover analysis of mutant human apurinic/apyrimidinic endonuclease. Biochemistry 38:4958-4964.

31. Lyons, M. S., B. Bell, D. Stainier, and K. G. Peters. 1998. Isolation of the zebrafish homologues for the tie-1 and tie-2 endothelium-specific receptor tyrosine kinases. Dev. Dyn. 212:133-140.

32. Lyons, S. E., N. D. Lawson, L. Lei, P. E. Bennett, B. M. Weinstein, and P. P. Liu. 2002. A nonsense mutation in zebrafish gata1 causes the bloodless phenotype in vlad tepes. Proc. Natl. Acad. Sci. USA 99:5454-5459.

33. Marenstein, D. R., D. M. Wilson III, and G. W. Teebor. 2004. Human AP endonuclease (APE1) demonstrates endonucleolytic activity against AP sites in single-stranded DNA. DNA Repair 3:527-533.

34. Mitra, S., T. Izumi, I. Boldogh, K. K. Bhakat, J. W. Hill, and T. K. Hazra. 2002. Choreography of oxidative damage repair in mammalian genomes. Free Radic. Biol. Med. 33:15-28.

35. Mol, C. D., T. Izumi, S. Mitra, and J. A. Tainer. 2000. DNA-bound structures and mutants reveal abasic DNA binding by APE1 and DNA repair coordination. Nature 403:451-456.

36. Mundle, S. T., M. Fattal, L. M. Melo, and P. R. Strauss. 2004. A novel mechanism for human AP endonuclease 1. DNA Repair 3:1447-1455.

37. Nakamura, J., and J. A. Swenberg. 1999. Endogenous apurinic/apyrimidinic sites in genomic DNA of mammalian tissues. Cancer Res. 59:2522-2526.

38. Robson, C. N., and I. D. Hickson. 1991. Isolation of cDNA clones encoding a human apurinic/apyrimidinic endonuclease that corrects DNA repair and mutagenesis defects in Escherichia coli xth (exonuclease III) mutants. Nucleic Acids Res. 19:5519-5523.

39. Sambrook, J., E. F. Fritsch, and T. Maniatis. 1989. Molecular cloning: a laboratory manual, 2nd ed. Cold Spring Harbor Laboratory Press, Cold Spring Harbor, N.Y.

40. Scherer, S. J., S. M. Maier, M. Seifert, R. G. Hanselmann, K. D. Zang, H. K. Muller-Hermelink, P. Angel, C. Welter, and M. Schartl. 2000. p53 and c-Jun functionally synergize in the regulation of the DNA repair gene hMSH2 in response to UV. J. Biol. Chem. 275:37469-37473.

41. Strauss, P. R., W. A. Beard, T. A. Patterson, and S. H. Wilson. 1997. Substrate binding by human apurinic/apyrimidinic endonuclease indicates a Briggs-Haldane mechanism. J. Biol. Chem. 272:1302-1307.

42. Strauss, P. R., and N. E. O'Regan. 2001. Abasic site repair in higher eukaryotes, p. 43-85. In J. A. Nickloff and M. F. Hoekstra (ed.), DNA damage and repair, vol. 3. Humana Press, Inc., Totowa, N.J.

43. Sumoy, L., J. B. Keasey, T. D. Dittman, and D. Kimelman. 1997. A role for notochord in axial vascular development revealed by analysis of phenotype and the expression of VEGR-2 in zebrafish fih and $n t l$ mutant embryos. Mech. Dev. 63:15-27.

44. Sung, J. S., and B. Demple. 2006. Roles of base excision repair subpathways in correcting oxidized abasic sites in DNA. FEBS J. 273:1620-1629.

45. Szeto, D. P., K. J. Griffin, and D. Kimelman. 2002. HrT is required for cardiovascular development in zebrafish. Development 129:5093-5101.

46. Thisse, C., and L. I. Zon. 2002. Organogenesis: heart and blood formation from the zebrafish point of view. Science 295:457-462.

47. Vasko, M. R., C. Guo, and M. R. Kelley. 2005. The multifunctional DNA repair/redox enzyme Ape1/Ref-1 promotes survival of neurons after oxidative stress. DNA Repair 4:367-379.

48. Walker, L. J., C. N. Robson, E. Black, D. Gillespie, and I. D. Hickson. 1993. Identification of residues in the human DNA repair enzyme HAP1 (Ref-1) 
that are essential for redox regulation of Jun DNA binding. Mol. Cell. Biol. 13:5370-5376.

49. Wallace, S. S. 2002. Biological consequences of free radical-damaged DNA bases. Free Radic. Biol. Med. 33:1-14.

50. Walton, R. Z., A. E. Bruce, H. E. Olivey, K. Najib, V. Johnson, J. U. Earley, R. K. Ho, and E. C. Svensson. 2006. Fog1 is required for cardiac looping in zebra fish. Dev. Biol. 289:482-493.

51. Westerfield, M. 1995. The zebrafish book, 3rd ed. University of Oregon Press, Eugene.

52. Wilson, D. M., III. 2003. Properties of and substrate determinants for the exonuclease activity of human apurinic endonuclease Ape1. J. Mol. Biol. 330:1027-1037.

53. Wilstermann, A. M., and N. Osheroff. 2003. Stabilization of eukaryotic to- poisomerase II-DNA cleavage complexes. Curr. Top. Med. Chem. 3:321338 .

54. Winnier, G., M. Blessing, P. A. Labosky, and B. L. Hogan. 1995. Bone morphogenetic protein-4 is required for mesoderm formation and patterning in the mouse. Genes Dev. 9:2105-2116.

55. Xanthoudakis, S., G. Miao, F. Wang, Y. C. Pan, and T. Curran. 1992. Redox activation of Fos-Jun DNA binding activity is mediated by a DNA repair enzyme. EMBO J. 11:3323-3335.

56. Yamakoshi, K., and N. Shimoda. 2003. PCR-based cloning of an intronless zebrafish no tail gene. Biochem. Biophys. Res. Commun. 306:598-602.

57. Yu, S. L., S. K. Lee, R. E. Johnson, L. Prakash, and S. Prakash. 2003. The stalling of transcription at abasic sites is highly mutagenic. Mol. Cell. Biol 23:382-388. 